Skiing, Science and Sovereignty: A Material and Political History of the Road to Hawai'i’s Mauna Kea (1936-2020)

Pascal Marichalar, CNRS, Institut de recherches interdisciplinaires sur les enjeux sociaux, France.

postprint version (after peer-review, prior to formatting)

\title{
Article Body
}

In 1921, a Hawaiian businessman named Lorrin Thurston expressed his dream of building a road up to the summit of Mauna Loa, one of the two tallest volcanoes on Hawai'i Island (also known as the Big Island). His main motivation for this project was skiing, an activity that was becoming increasingly popular among the upper classes of North America and Europe (Denning 2014). During the winter months, it was not uncommon for snow to fall on Mauna Loa and Mauna Kea, and sometimes even on Hawai‘i Island’s lower Hualālai and Maui’s Haleakalā (Schorghofer, Kantar and Nogelmeier 2014).

A journalist for one of Hawai'i’s two main English language newspapers, the Honolulu Star-Bulletin, described Thurston's project thus: 
The final version of this paper was published as Pascal Marichalar (2021, ahead-of-print) «Skiing, science and sovereignty: A material and political history of the road to Hawai'i's Mauna Kea (1936-2020) », History and Anthropology, DOI: 10.1080/02757206.2021.1983562

It would make possible surfing at Waikiki and ski-ing in mountain snow within a space of 24 hours—one afternoon sea bathing in the tropics, the next the mountain sports of Switzerland. No other resort on Earth could offer such an attraction to tourists. Nature has lavishly endowed Hawaii, has made this territory a playground second to none in its variety of scenery and natural wonders, but little has yet been done by man to make these works of the Master Architect accessible to those who would see them. (HSB 1921)

Thurston was an important figure of Hawaiian politics. In 1893, the descendant of American missionaries had been one of the initiators of the overthrow of the Hawaiian monarchy, with the support of the U.S Navy. The newspaper he owned, the Pacific Commercial Advertiser, relentlessly advocated for American control of the islands. This occurred in 1898 when the U.S. unilaterally annexed Hawai'i through a joint resolution of Congress, ignoring the many Native Hawaiians who protested through mass petitions (Silva 2004).

The businessman's idea of a summit access road for Mauna Loa was inkeeping with the spirit of the times. In the 1910s, Thurston had already helped volcanologist Thomas Jaggar establish Hawaii National Park to preserve Hawai'i’s volcanic curiosities and market them to the world. The park's boundaries encompassed the active Kîlauea and the more unpredictable Mauna Loa (as well as Haleakalā on Maui), but left out Hawai‘i Island’s tallest mountain, Mauna Kea, also known as Mauna a Wākea, a volcano which scientists then considered extinct (it has been reclassified since as merely dormant) (Shih 2019). In the 1920s, the increase in automobile use and the access to federal tax revenues sparked the territorial government's interest in roads (Duensing 2015). Many among the political-economic elite thought that with adequate roads, 
The final version of this paper was published as Pascal Marichalar (2021, ahead-of-print) «Skiing, science and sovereignty: A material and political history of the road to Hawai'i's Mauna Kea (1936-2020) », History and Anthropology, DOI: 10.1080/02757206.2021.1983562

even sites such as Hawai ‘i Island’s two tallest mountains would offer opportunities for economic development.

Mauna Loa’s access road was eventually completed at the beginning of the 1950s, in circumstances which will be touched upon below. This article chooses to focus on the history of another road, leading to the summit of Mauna Kea. The latter was also envisioned as a possible ski venue, from the 1930s onward. Three decades later, in the wake of Hawaiian statehood, Mauna Kea was 'discovered' by astronomers as an excellent site for the observation of the night sky (Marichalar 2021). The construction of many world-class telescopes between the 1970s and 1990s transformed it into the foremost site for astronomical research in the Northern hemisphere. In the 2010 decade, Mauna Kea became familiar to many in the Pacific and around the world as a result of the massive mobilizations which opposed self-identified kia'i (protectors) to the supporters of the construction of a giant Thirty Meter Telescope (TMT). The attempted 'groundbreaking' and later construction of the eighteen-story-high TMT at the summit were halted by what were first hundreds, later thousands of kia‘i, drawing global media coverage and international support. The kia'i resisted the project with arguments of environmental conservation as well as Hawaiian sovereignty. They recalled in particular that the so-called 'ceded' lands (formerly known as Hawaiian Government and Crown lands) on which most of the existing astronomical facilities and infrastructure were built, had been claimed as the Hawaiian State’s property only as a result of the illegitimate 1893 overthrow and 1898 annexation (Case 2019; Fujikane 2019; Casumbal-Salazar 2019). 
The final version of this paper was published as Pascal Marichalar (2021, ahead-of-print) «Skiing, science and sovereignty: A material and political history of the road to Hawai'i's Mauna Kea (1936-2020) », History and Anthropology, DOI: 10.1080/02757206.2021.1983562

In this article, I choose to study the inseparably material and political history of the road leading to Mauna Kea’s summit. I pay close attention to economic interests, political conflicts, and relations of domination, which are intertwined with the very materiality of the road: its route, surface, safety, maintenance, as well as features such as cattle guards, crosswalks, and guardrails. Why focus on a road? Because roads are technologies of power, through which humans extend their mastery of nature, and colonists assert their rule over territory through the creation of new landscapes (Freed 2010). Roads can connect and equalize, and roads can also separate and segregate (Bayor 1988; Mohl 1993; Sugrue 2014, 47-48, 242). Roads can be more or less easy to travel, and more or less open to travellers; roads can be blocked.

Roads are also land, and can give value to land, and land tenure is a crucial issue in Hawaiian politics since the mid- $19^{\text {th }}$ century at least. The Māhele (partition, division, sharing) of 1848, decided under King Kamehameha III, replaced a system of land use based on reciprocity and kuleana (responsible stewardship, caretaking) with a Western-inspired notion of land as private property that could be alienated. Native Hawaiians eventually lost most of their effective rights to land, although there are debates about the exact timeframe, legality and means through which this happened (Kauanui 2018, ch. 2; Stauffer 2004). The political sequence of the 1890s, through violence and the threat of violence, undoubtedly contributed to assert the power of sugarcane (and later, pineapple) plantation owners over the vast expanses of arable land which ensured their wealth. 
The final version of this paper was published as Pascal Marichalar (2021, ahead-of-print) «Skiing, science and sovereignty: A material and political history of the road to Hawai'i's Mauna Kea (1936-2020) », History and Anthropology, DOI: 10.1080/02757206.2021.1983562

As of the mid-1950s, the Democratic takeover of the Territorial government contributed to a shift in the identity of those who profited from land ownership. Hawai'i's 'admission' to the United States as the $50^{\text {th }}$ State in 1959 , the concomitant boom of tourism and military spending, and the gradual decline of the sugar and pineapple industries, all fostered intense speculation on land, often involving the officials from zoning authorities (Cooper and Daws 1985). As of the 1960s, resistance against touristic and economic overdevelopment linked up with the rise of modern environmentalism and the rebirth of the Hawaiian sovereignty movement (GoodyearKa‘ōpua 2014). These social mobilizations were experienced and analyzed at once as a critique of settler colonial land expropriation and dispossession (in the language of property rights), as well as a contemporary reinvention of traditional caretaking practices that consider land not as an alienable commodity but as the structuring principle of 'aina (nourishing land).

The methodological approach followed here is one of social history and historical ethnography. The article is informed by oral history interviews and archival research conducted by the author with anthropologist Benoît Trépied in Hilo and Waimea, Hawai'i Island, in January-February 2020. My main source is the English-language newspaper record: Thurston’s Honolulu Advertiser (as it came to be called after 1921) and its rival the Honolulu Star-Bulletin (both merged in 2010 to become the Honolulu Star-Advertiser); the Hawai'i island newspaper the Hilo Daily Tribune (renamed the Hilo Tribune-Herald in 1921, and the Hawaii TribuneHerald in 1964), and its offshoot West Hawaii Today; for the 2010s, local information website Big Island Video News. Though I had to leave out Hawaiian-language newspapers (which ran 
The final version of this paper was published as Pascal Marichalar (2021, ahead-of-print) «Skiing, science and sovereignty: A material and political history of the road to Hawai'i's Mauna Kea (1936-2020) », History and Anthropology, DOI: 10.1080/02757206.2021.1983562

until the end of the 1940s) for want of linguistic skills, their systematic study would probably give more visibility to the agency of Native Hawaiians in the early history of roads around Mauna Kea, in particular concerning summit paths and road labor.

Between the 1930s and 2020, three distinct and overlapping political strategies centrally involved the notion of a Mauna Kea access road. Starting in the 1930s, businessmen and government officials pushed for a road, and later for the improvement of the latter, in order to make the mountain more accessible. For supporters of touristic development, Mauna Kea was seen as a potential 'playground of the Pacific' (HTH 1944). Later, for astronomers, it was 'probably the best site in the world from which to study the Moon, the planets, the stars' (Kuiper 1964).

However, as of the 1960s, this push was paralleled and contradicted by another strategy, which consisted in keeping the mountain not too accessible, because of what some perceived as a competition between recreational and scientific uses - skiing vs. science. Limited accessibility went hand in hand with the idea of filtered access. Supporters of this perspective went so far as to sometimes view positively the incomplete and hazardous quality of the summit access road.

A third political strategy involved the road as a site to affirm sovereignty. In the 2010s, the kia'i of Mauna Kea that opposed the construction of the TMT were first blocked by rangers; then resorted to blocking the access road themselves, successfully freezing the observatory project. The road appeared then as the weak link in the State's pretentions to sovereignty, as well as the 
The final version of this paper was published as Pascal Marichalar (2021, ahead-of-print) «Skiing, science and sovereignty: A material and political history of the road to Hawai'i's Mauna Kea (1936-2020) », History and Anthropology, DOI: 10.1080/02757206.2021.1983562

stronghold from which the kia‘i could affirm their own claims of sovereignty over Mauna Kea, and more generally, over Hawaiian land.

\section{'Mauna Kea Goes Alpine!'}

In the early morning of Friday 7 February 1936, Leicester Winthrop 'Bill' Bryan and his ten-year-old son Jack got dressed in winter clothes and drove off in a truck to the lower slopes of Mauna Kea. They were going skiing.

Bill Bryan had started working on the mountain shortly after arriving in Hawai'i in the spring of 1921. Trained in forestry at the Massachussets Agricultural College, he had found a job on Hawai‘i Island working for the Hawaiian Sugar Planters’ Association, which was the main economic and political force in the archipelago (HSB 1984; HTH 1985; Whitten 1985). In 1922, the governor of the Territory of Hawaii had decided that something had to be done to protect Hilo’s water resources from the cattle grazing on Mauna Kea’s lower slopes. The planters agreed: they would reserve native koa and 'ōhi'a forests on their lands to prevent the extension of pastures. Bryan worked under the supervision of L.L. Peralto, a forest ranger employed by the territorial board of agriculture and forestry, though he continued to be on the planters' payroll. Both men supervised the erection of a cattle-proof fence to separate the pastures from the forest reserves, fence which they lined with fast-growing lemon-scented eucalyptus (HDT 1922). Eventually Bryan became a direct employee of the Territory as a forester on Mauna Kea. 
The final version of this paper was published as Pascal Marichalar (2021, ahead-of-print) «Skiing, science and sovereignty: A material and political history of the road to Hawai'i's Mauna Kea (1936-2020) », History and Anthropology, DOI: 10.1080/02757206.2021.1983562

The Depression had hit the US territory of Hawai‘i hard. In 1935, a camp had been installed in Pōhakuloa, near the saddle between Mauna Loa and Mauna Kea, to house 50 'boys' of the Civilian Conservation Corps, a New Deal program which used conservation work (in particular forestry) as a way to employ and train young, male adults (Judd 1935; Pacific Consulting Serices 2010). Bryan was asked to supervise projects for the CCC. The exceptionally heavy snowfalls in February 1936 made life miserable for the young men, who slept in tents, but they provided Bryan with a new idea. The forester had skied some twenty years earlier on the mainland. Since then, the activity had become fashionable among the North American upper classes (Denning 2014). What if skiing were possible here too?

That morning of 1936, after parking the truck at the Pōhakuloa camp, the father and son hiked until they found a mile-long stretch of snow with a relatively steep slope. Somebody probably one of the CCC boys - took a picture of them smiling on their wooden skis. The next Monday, the Hilo Tribune-Herald printed it under the headline 'Mauna Kea goes alpine!' Bill and Jack Bryan were announced to be the first people to ever ski on the mountain (HTH 1936).

\section{BUILDING THE 'CCC TRAIL'}

At the moment of the Bryan ski expedition, only one of the four highest peaks in the archipelago was accessible by a paved road: Maui's Haleakalā, which boasted a highly drivable new highway completed in 1935. Haleakalā Highway came to be only because 'Hawai'i's leaders publicly and aggressively advocated scenic roads as commercial enterprises to help 
The final version of this paper was published as Pascal Marichalar (2021, ahead-of-print) «Skiing, science and sovereignty: A material and political history of the road to Hawai'i's Mauna Kea (1936-2020) », History and Anthropology, DOI: 10.1080/02757206.2021.1983562

establish tourism as the islands' third industry after sugar and pineapple’ (Duensing 2009, 304). In this history, the rivalry between Maui and Hawai‘i Island played a great part. The Maui business community had long been jealous of the influx of tourists attracted to the easily accessible and usually active Kīlauea, an obligatory stop on most steamer tours. Maui secured funding for the highway as part of the National Recovery Act of 1933. Haleakalā was considerably lower than Mauna Kea and Mauna Loa, and therefore saw much less snow, even though 'in January 1936, an unusually heavy snowstorm lured Mauians to the summit', stranding dozens of cars (Duensing 2009, 323) - the same snowstorm that incited the Bryans to ski on Mauna Kea.

Bill Bryan knew that skiing would only stand a chance of becoming a regular activity on Mauna Kea if there was easier access to a higher altitude. The forester lacked funding, but he had the manpower. The CCC 'boys’ were the latest in the long history of cheap and indentured labor used to build Hawai ‘i’s roads ever since European missionaries had established themselves on the islands. As one missionary noted in the $19^{\text {th }}$ century, 'adultery built the road system in Hawaii' (Kauanui, 2018, 137), as labor in construction crews was one of the main penalties for Native Hawaiians who disregarded the new laws about sexuality and marital life. Prison labor would continue to play a major role in roadwork well into the $20^{\text {th }}$ century.

In the summer of 1936, the CCC completed a new 'four foot wide, clearly defined trail (...) marked every few feet by large piles of stone which are easily discernible even in heavy snow or fog'. It went from a ranger outpost near the Humu'ula sheep station, in the saddle between 
The final version of this paper was published as Pascal Marichalar (2021, ahead-of-print) «Skiing, science and sovereignty: A material and political history of the road to Hawai'i's Mauna Kea (1936-2020) », History and Anthropology, DOI: 10.1080/02757206.2021.1983562

Mauna Loa and Mauna Kea, to the summit of the latter, and allowed hikers or skiers to continue easily on foot or horseback after parking their car (HTH 1937a). The young men also built a rest house about an hour up from the ranger outpost, at the 9500 foot elevation, which they named Hale Pōhaku (stone house).

The snow returned at the beginning of 1937, albeit at a considerably higher altitude than the previous year. In the meantime, the CCC had continued to work to improve the road to the rancher station, and the ascent was now easier for common vehicles. One Sunday, Bryan noted with satisfaction that 25 cars were parked there (HTH 1937b). More than 150 people visited the trail during a single weekend in February 1937, and probably more than 1000 during the whole season. Bryan and others were filmed by a movie crew as they skiied down from one of the higher cinder cones at the 12,035-foot elevation, very near the summit. A handful of winter sports enthusiasts decided to found a Hilo Ski Club.

Mauna Kea leisure expeditions were a mostly male affair, involving Boy scouts, CCC 'boys' and other men who felt they could demonstrate thus their resistance and adventurous spirit. Not before January 1939 did a handful of women take part in the snow sports, and this was considered extraordinary enough to be reported (HTH 1939a). As early as 1937, Mauna Kea skiing was integrated into tour packages proposed to Japanese tourists who had come to Hilo to see Kīlauea’s bubbling lava. Skiing was an activity which attracted mainly the wealthy elite of European descent and tourists, at a moment when there was probably no more than one car per 
The final version of this paper was published as Pascal Marichalar (2021, ahead-of-print) «Skiing, science and sovereignty: A material and political history of the road to Hawai'i's Mauna Kea (1936-2020) », History and Anthropology, DOI: 10.1080/02757206.2021.1983562

hundred inhabitants on the island - and then only the most powerful cars could manage the steep grade.

The only people involved with Native Hawaiian ancestry were those whose job brought them to roam the mountain: ranch hands and shepherds at Humu'ula sheep station (which also employed many Japanese), Parker Ranch paniolos (cowboys) who served as guides to groups of tourists, and forest rangers such as Duke Kawai, whom Bryan charged with patrolling the access trail on Sundays to make sure the fences were properly closed and the shelter was left clean (HTH 1939b; Bergin, 2004).

In 1939, efforts were stepped up to make Mauna Kea even more accessible. Bill Bryan assigned the CCC a new mission of road improvement: 'Within the next two months hikers up Mauna Kea will be able to drive their cars up to the Hale Pōhaku resthouse, which is two and a half miles from the parking space now allotted for hikers,' the forester announced in February (HTH 1939b). The improved road would become what on the island was known as a 'truck trail' or 'Jeep trail,' an unpaved road suited to all-terrain vehicles. The CCC was also tasked with building a second, much larger resthouse at the Hale Pōhaku site. Both units together could accomodate 60 guests at a time (HTH 1939d, 1939e).

The Project of A SADDLE RoAd

Facilitating access to Mauna Kea also involved improving the portion of the trip between Hilo’s outskirts and the Humu'ula sheep station, which marked the beginning of the CCC trail. In 
The final version of this paper was published as Pascal Marichalar (2021, ahead-of-print) «Skiing, science and sovereignty: A material and political history of the road to Hawai'i's Mauna Kea (1936-2020) », History and Anthropology, DOI: 10.1080/02757206.2021.1983562

1939, the Hilo Ski Club petitioned the territorial legislature to have a properly paved 'Saddle Road' until the depression between Mauna Loa and Mauna Kea, and suggested the road might even be continued until the Kona coast. According to one member of the ski club, the petition was 'ridiculed' (HTH 1939c). Some noted the proposed road would open access to homesteads which would have no water supply. Others considered the money would be better used on the busy Hāmākua road, which connected the important Kohala and Honoka'a sugar plantations to Hilo via the northwest side of Mauna Kea.

In February 1941, a group of State senators revived the issue, insisting on the fact that a Saddle Road would facilitate the development of the dry west coast and have agricultural and military value, on top of providing 'easier access to the snow fields' and thus 'an additional tourist attraction' for the island (HTH 1941). In March, four representatives at the State house filed a joint resolution 'requesting the director of institutions to place the prisoners of Waiakea prison camp at work on the clearing and grading' of such a road (HSB 1941). As representative Thomas Pedro explained to a journalist:

While there is a possibility of getting federal funds to put this road through, there is no reason to sit back and do nothing. With the prisoners at work there much of the preliminary clearing and grading could be finished. At the same time the prisoners would get a real workout at hard labor. (Bennett Hill 1941)

The opening of the Pacific war theatre was a gamechanger. In 1942, the army, under the command of Maj. Gen. Ralph McT. Pennell, rapidly completed a proper 'truck trail' from Hilo to the saddle between the two volcanoes. This was part of a broader military program which 
The final version of this paper was published as Pascal Marichalar (2021, ahead-of-print) «Skiing, science and sovereignty: A material and political history of the road to Hawai'i's Mauna Kea (1936-2020) », History and Anthropology, DOI: 10.1080/02757206.2021.1983562

established a training unit around the Pōhakuloa CCC camp and a large Marine camp in Waimea as of 1943. The new Saddle Road could only be used by the military.

In 1944, as the war dragged to an end, Big Island-based State representative William J. Payne noted that 'during the last two years the county has had more money than at any other time for road work.' As part of his reelection bid, he pressed for completing the road from Pōhakuloa down to Kona and opening it to everyone. Tourism and leisure were on his mind: 'Mauna Kea should be made a part of the Hawaii National Park and could be made the playground of the Pacific', he stated (HTH 1944).

In February 1946, Bryan went driving on Saddle Road with Harry M. Blickhan, the editor of the Hilo Tribune-Herald. Though the war was over, the road was still restricted to military use, and like other civilians they had to apply in advance for a one-time permit from the provost marshal. There was talk of the Army turning the road over to the Territory or the County once the Marines had left, but there were many administrative hurdles. Bryan nevertheless expressed his renewed optimism about plans to develop the mountain. 'A hunting lodge up here', he said, as he pointed to the thickets around Humu'ula sheep station, 'would be ideal'. The forester was concerned with the fact that thousands of feral sheep were destroying the trees by treading on their roots, and thought hunting might be a good way to control their population while providing a new recreational activity. 'Even a golf course would be perfect there', the forester noted, indicating a grassy plateau. The newspaper editor who accompanied him nodded: 'Roads. We've got to have roads’' (Thompson 1946). 
The final version of this paper was published as Pascal Marichalar (2021, ahead-of-print) «Skiing, science and sovereignty: A material and political history of the road to Hawai'i's Mauna Kea (1936-2020) », History and Anthropology, DOI: 10.1080/02757206.2021.1983562

\section{AtTRACTING SCIEnTISTS TO THE MOUnTAins}

The Saddle Road was eventually opened to civilian use but it became infamous for its state of disrepair. As for the road up Mauna Kea, it would make no progress until the summer of 1963, when the Executive Secretary of the Hawai`i Island Chamber of Commerce decided that science, rather than skiing, might be the key to the economic development of Hawai'i’s tallest mountains. So went one of the letters he sent to universities in the mainland United States and Japan:

The Hawai'i Island Chamber of Commerce is seriously considering the possibility of undertaking a study as to the feasibility of using the two mountains on our island, namely Mauna Kea and Mauna Loa, considered the tallest island mountains in the world ${ }^{1}$, for facilities undertaking solar research as well as for space vehicle launching program [sic]. (Akiyama 1963)

The author of these promotional letters was Mitsuo Akiyama, a 43-year-old insurance salesman and real estate agent, who like many other businessmen of Japanese origin was wellconnected to the political elite since the Democratic Party had taken over Hawai'i’s government in the mid-1950s. In 1959, Hawai'i’s status had changed from that of Territory to $50^{\text {th }}$ US State. This ‘admission’ to the Union was generally presented as a positive development, as it granted federal representation to the inhabitants, yet it also contributed to further erase the violent history through which the United States had taken control of the islands. Coupled with the new direct jet service between the mainland and Honolulu (also in 1959), Hawaiian statehood also marked a distinct acceleration in what was called 'development' (McGregor, 2010). Until then, most large

1 When measured from their underwater base. 
The final version of this paper was published as Pascal Marichalar (2021, ahead-of-print) «Skiing, science and sovereignty: A material and political history of the road to Hawai'i's Mauna Kea (1936-2020) », History and Anthropology, DOI: 10.1080/02757206.2021.1983562

estates and ranches had held on to their land, the value of which they deliberately undervalued in order to minimize taxes. However, the prospect of touristic development suddenly made it more interesting to sell, if possible at a high price. The gradual demise of the sugarcane and pineapple industries provided yet more land for uses other than agriculture. More than ever before, land was viewed as a commodity, which was ideally bought cheap and sold shortly after for many times the initial price, providing that influential members of the zoning authorities were cared for in the real estate hui (partnership). The most inhospitable tracts of land, such as the Puna lava fields on Hawai`i Island with no connection to utilies and at severe risk of lava flows, were successfully sold to U.S. mainland inhabitants who did not visit the property prior to purchase (Cooper and Daws, 1985).

It can seem surprising that a real estate agent such as Akiyama should include Hawai‘i Island's tallest mountains on the list of developable land, considering that the Mauna Kea lands were part of the State's 'ceded lands trust', also known as 'public trust lands', which comprise former Crown lands which are in principle inalienable and must be managed for the benefit of the public of Hawai'i and in particular, Native Hawaiians (for lands managed by the Department of Hawaiian Home Lands). However, if a profit was not to made from the mountain land itself, the prospect of luring world-class astronomers to the island certainly enhanced the prospects for residential development in the towns of Hilo and Waimea, as well as for infrastructure (in particular, roads) to service the mountain. 
The final version of this paper was published as Pascal Marichalar (2021, ahead-of-print) «Skiing, science and sovereignty: A material and political history of the road to Hawai'i's Mauna Kea (1936-2020) », History and Anthropology, DOI: 10.1080/02757206.2021.1983562

Thomas Hamilton, the President of the University of Hawai`i, wrote back to Akiyama in July 1963:

We have no doubt that Mauna Loa and Mauna Kea are destined to play an important role in the future of astronomical observing sites. Clearly this role is dependent on the accessibility of such sites. We should like to encourage the people of the island of Hawaii to do everything possible to help provide access to these sites. Perhaps the answer for the future will not be in roads but in helicopters. (Hamilton 1963, quoted in Maly \& Maly 2005, 566)

In fact, at this date access was no longer an issue for Mauna Loa. Thurston's dream of a Mauna Loa road which would allow skiing and surfing in the same day had been taken seriously, from the moment that science had entered the picture as a more legitimate yet complementary goal to skiing. In 1948, the Honolulu Advertiser featured a front-page interview of meteorologist Robert H. Simpson, who advertised Mauna Loa’s summit as a potentially excellent site for an atmospheric observatory. As Simpson later recalled in a biographical interview:

To my surprise, only two days later, I received a call from a man by the name of Tom Vance, Director of Institutions in Hawaii who said, "I think we might be able to do business together in achieving our common interests in Mauna Loa. I have a prison camp at Kulani deep in the rain forest at the 5,000 feet level on Mauna Loa”. (Mims 2012, 54)

This was the prison, inaugurated in 1946, that had warranted the opening of a first stretch of road up Mauna Loa. According to Thomas Vance:

The inmates there need a challenge to help equip them to be responsible citizens when they leave prison. They can help both in road building and in construction of the observatory building. (Mims 2012, 54)

Simpson was thrilled. Only later did Vance confess to the scientist that 'what he really wanted to do was establish a ski lodge at the summit to be operated by the inmates.' When it 
The final version of this paper was published as Pascal Marichalar (2021, ahead-of-print) «Skiing, science and sovereignty: A material and political history of the road to Hawai'i's Mauna Kea (1936-2020) », History and Anthropology, DOI: 10.1080/02757206.2021.1983562

appeared that prison labor could not be employed directly by the territorial administration for a legal reason, Simpson and Vance came up with a workaround: the Hilo Lions Club would endorse the project and pay for the prison labor, in exchange for a share in the profits of an eventual ski lodge. The US Navy accepted to lend two pieces of heavy equipment to cut through the lava.

The road reached the summit of Mauna Loa in the fall of 1951, and a first atmospheric observatory was immediately installed. At a meeting of the Hawaii Island Chamber of Commerce that same fall, Thomas Vance repeated that Mauna Loa snows 'would afford a perfect setup for ski jump meets by experts,' which could 'bring wide and unusual publicity to the Big Island' (HTH 1951a). He was in for a disappointment, as skiing afficionados quickly realized that 'the rocky and lava terrain [on Mauna Loa] would never be suitable for good skiing' (Olival 1955). All such projects for Mauna Loa were dropped, but the road and the atmospheric observatory lived on.

As for the easily accessible Haleakalā on Maui, a 1955 report funded by sugar and pineapple planters had called for what it considered to be the most sensible way to develop its summit: the construction of a solar observatory (HTH 1955), inkeeping with the mountain's name (the house of the Sun). It was dedicated in January 1964 (HSB 1961; HTH 1963).

Only one person replied with marked interest to Akiyama’s proposal: the Dutch-American astronomer Gerard Kuiper, from the University of Arizona, who had been prospecting for many years for a high altitude infrared observatory to study the planets and the Moon. He quickly 
The final version of this paper was published as Pascal Marichalar (2021, ahead-of-print) «Skiing, science and sovereignty: A material and political history of the road to Hawai'i's Mauna Kea (1936-2020) », History and Anthropology, DOI: 10.1080/02757206.2021.1983562

realized that Mauna Loa was out of the question for an optical observatory: millions of dollars of sensitive equipment and finely polished mirrors could not be placed atop a volcano which periodically spewed molten rock and gas into the air. As for Mauna Kea, it of course interested Kuiper because of its very high altitude, which placed it above cloud cover as well as of much of the Earth's atmosphere, opening up new possibilities for infrared observation, but it lacked a proper access road to its summit.

\section{BuILDing THE MAUnA KeA SUMmit RoAD}

Since the 1930s, the CCC trail to Hale Pōhaku had been improved only marginally. In 1951, Bill Bryan had made sure that the worst mile was properly graded and 'in many places, given a hard oiled surface' (HTH 1951b). The trail had also been extended for a mile and a half beyond Hale Pōhaku, until a newly developed picnic area named Kilohana (the lookout) at an elevation of about 9,000 feet, which was the last stop for cars and trucks.

In January 1964, Gerard Kuiper came to the Big Island at Mitsuo Akiyama’s invitation. After flying his guest over Mauna Kea, one of the first things that the Hilo businessman organized was a meeting between the two of them and Governor Burns, who immediately agreed to build a 'Jeep road' to the summit (Warshauer 2001). At the beginning of April, a \$42,000 contract was signed with Kuwaye Brothers, Inc. from Hilo, for the section between Kilohana and the summit, and an additional \$8,000 were allocated to the improvement of the existing road between the Saddle Road (Humu'ula sheep station) and Hale Pōhaku. The work was carried out 
The final version of this paper was published as Pascal Marichalar (2021, ahead-of-print) «Skiing, science and sovereignty: A material and political history of the road to Hawai'i's Mauna Kea (1936-2020) », History and Anthropology, DOI: 10.1080/02757206.2021.1983562

immediately and the road was ready by the end of April. Instead of the geographical summit, the gravel road reached one slightly lower summit peak, a cinder cone named Pu'u Poliahu (at 13,600 feet) which Kuiper and Herring had identified as a potentially good site to erect a test telescope.

The first tests demonstrated that Mauna Kea’s summit was indeed excellent for astronomical observation. On July 20, 1964, Kuiper gave an enthusiastic speech at the dedication ceremony for the small telescope: 'This mountaintop is probably the best site in the world - I repeat - in the world, from which to study the Moon, the planets, the stars.' (Kuiper 1964) The reference to the Moon was important, as the Apollo program was in full sway, justifying grants for telescopes that would help map the lunar surface. ${ }^{2}$ In the fall, Kuiper asked John Jefferies, the newly hired head of the astronomy program at the University of Hawai'i, if he would be willing to endorse a grant application for a larger, permanent telescope, because the funder, NASA, considered Kuiper's project would be more realistic if it was supported by the University of Hawai'i.

Jefferies first agreed, but when he learned that astronomers at Harvard University were also thinking of bidding for the same grant, he changed his mind:

So the University of Hawai'i was in a position of hearing from these two outside groups that they had designs on a mountain which, I suppose, could reasonably have been regarded as under Hawai’i’s jurisdiction, and yet no one was talking to the University of Hawai’i. (Weart 1977)

2 Hi`ilei Julia Hobart (2019) also shows that in the 1960s and early 1970s, Mauna Kea was used, along with other Hawaiian volcanoes (especially Mauna Loa), as a training site for Apollo astronauts heading for the Moon. 
The final version of this paper was published as Pascal Marichalar (2021, ahead-of-print) «Skiing, science and sovereignty: A material and political history of the road to Hawai'i's Mauna Kea (1936-2020) », History and Anthropology, DOI: 10.1080/02757206.2021.1983562

Jefferies decided he would draft an independent application on behalf of UH. He knew he held a trump card in the competition with Harvard and the University of Arizona: because of the close ties between the UH and the State Government, he would be able to guarantee the construction of a proper access road (Jefferies n.d.). The final proposal which UH submitted to NASA in February 1965 announced that the State would contribute the \$2 million necessary for a blacktopped summit access road, a power line, modern mid-altitude accomodation at Hale Pōhaku and a few scientific staff positions. On July 1, 1965, Jefferies learned that the UH application had been accepted and in March 1966, after additional testing, he gave a green light to the construction of the telescope on Mauna Kea.

On July 1, 1967, Jefferies became the first director of a new autonomous research unit within the University of Hawai'i named the Institute for Astronomy (IfA), which secured legal control over the Mauna Kea summit lands, even though they officially belonged to the State. This was made through a lease of all (State-owned) lands above the 12,000-foot elevation on Mauna Kea to the Institute for Astronomy, for a yearly token sum of \$1. Lease number S-4191 had a duration of sixty-five years, starting on January 1, 1968 and running until 2033. It created a 'Mauna Kea Science Reserve’, 'being more specifically a buffer zone to prevent the intrusion of activities inimical to said scientific complex’ (as quoted in Swanner 2014, 183).

However, the project of a Mauna Kea summit road was bogged down by a severe conflict over its proposed route. Governor Burns was in favor of a westward route that would connect the summit to the ranching town of Waimea, and then to the dry Kona coast. In Waimea, Burns 
The final version of this paper was published as Pascal Marichalar (2021, ahead-of-print) «Skiing, science and sovereignty: A material and political history of the road to Hawai'i's Mauna Kea (1936-2020) », History and Anthropology, DOI: 10.1080/02757206.2021.1983562

envisioned a pleasant 'science city' which would be 'generated by the community of space scientists who will stare at the stars through giant telescopes at Mauna Kea's summit.' In his ideal plan, a four-year residential liberal arts college would contribute to the town's new intellectual atmosphere. From Waimea, located at an elevation of 2670 feet (810 meters), the road would then wind down to the dry lava plains of the Kona coast. Burns marketed this as the Big Island's 'Gold Coast,' soon to be 'dotted by a chain of hotels' thanks to the new jet airport being built.

None of this was to the liking of the Hawai'i Island Chamber of Commerce members, who were steadfast in their resolution to build a road down the southern side then east toward Hilo, which they insisted had more housing options, educational facilities, and industrial infrastructures (Baker 1967a).

The director of the Institute for Astronomy was in favor of Burn’s project. However, the conflict caused such immobility that in January of 1970 Jefferies finally consented to support improvement of the existing 'CCC road' to Hale Pōhaku (HA 1970). Because it was about to open its 150-inch telescope built with NASA funding, the Institute for Astronomy urgently needed to improve access, even though this would probably sound the death knell for other proposed routes. In 1972, \$2 million of State funds were allocated to the project for a 'paved, allweather road with a 20-foot pavement and four-foot shoulder on each side’ until Hale Pōhaku (HTH 1972b). 
The final version of this paper was published as Pascal Marichalar (2021, ahead-of-print) «Skiing, science and sovereignty: A material and political history of the road to Hawai'i's Mauna Kea (1936-2020) », History and Anthropology, DOI: 10.1080/02757206.2021.1983562

(UN)FINISHING THE ROAD

Whichever the chosen route, the Governor was adamant that the final road should not reach the summit of Mauna Kea: 'For at least the last mile or so of the route, the planned astronomical observatory on the mountain should be served by a cable car, monorail or similar transportation,' he declared in October 1967. Paradoxically, the point of such infrastructure would be to make the summit less, rather than more, accessible. The lease which effectively handed over the management of the summit's public lands to the Institute for Astronomy did not include an eventual road, and this worried Burns very much:

If a road goes in, public access to the site cannot be restricted, and eventually Mauna Kea's attractions for space scientists will no longer exist. (...) A public road cannot be closed to anyone.

The Governor argued that the fumes and headlights of increased car traffic would disturb astronomy, and that with a finished road 'it would be difficult to keep television towers and other developments off the top of the mountain' (Baker 1967b). He did not mention skiing, but it was probably also on his mind. The previous winter, Mauna Kea's summit area had hosted an important 'ski meet,' attracting a record 207 people over one weekend, including more than 50 competitors in a slalom race. The journalist who enthusiastically reported on the event for the Hilo Tribune-Herald was none other than Jack Bryan, who three decades earlier had been the first to ski on Mauna Kea with his father (Bryan 1967).

Not all proponents of astronomical development were in favor of the cable car option. Though John Jefferies clearly wished to restrict access to the summit, he was 'resolutely 
The final version of this paper was published as Pascal Marichalar (2021, ahead-of-print) «Skiing, science and sovereignty: A material and political history of the road to Hawai'i's Mauna Kea (1936-2020) », History and Anthropology, DOI: 10.1080/02757206.2021.1983562

opposed' to the cable car, which he considered expensive and unrealistic (Jefferies n.d.). However, the Burns administration continued pushing the idea, and in 1972, the director of the State Department of Transportation, Fujio Matsuda, assured before the press that 'a combination roadway and cable car was being considered in plans for improved access to the summit of Mauna Kea’. The detailed plans called for a paved roadway from Saddle Road to Hale Pōhaku; then an improved gravel road; then a 'cable car or ropeway' for the last section until the summit.

Though such infrastructure is usually associated with winter sports, Matsuda made it clear that skiing was not as high as science on the State's priority list for Mauna Kea’s economic development. To the journalists present, he explained that the cable car would provide access to the summit under 'controlled conditions', because the State's objective was at once to 'provide easy access and preserve the mountain top primarily for scientific use'. Matsuda precised that 'skiers would not necessarily be precluded from using the cable car, but uses would be controlled by the University'. Though one cost study showed that the cable car would be about 25 per cent more expensive than the construction of a road which went all the way to the summit, the Director of Transportation argued that 'a few extra \$100,000 would be well worth spending if we could preserve the Mauna Kea’s scientific value’ (HTH 1972a).

John A. Burns was diagnosed with liver cancer in October 1973 and stepped down in favor of Lieutenant-Governor George R. Ariyoshi, who was elected governor in 1974. With Burn’s resignation (he died in 1975), contested proposals such as the Western access route to Mauna Kea and the summit area cable-car lost their most powerful backer. On May 30, 1974, Ariyoshi 
The final version of this paper was published as Pascal Marichalar (2021, ahead-of-print) «Skiing, science and sovereignty: A material and political history of the road to Hawai'i's Mauna Kea (1936-2020) », History and Anthropology, DOI: 10.1080/02757206.2021.1983562

inaugurated the improved section of the Southern road connecting Saddle Road to Hale Pōhaku. As planned, 'the road had been graded and paved with drainage, guard rails, cattle guards and fencing’ (Warshauer 2001).

The idea of a summit cable car would never be mentioned again. However, this was not the case of the general notion of restricting access in order to favor science, which lived on through Fujio Matsuda, Burns’ former Director of Transportation, who was elected President of the University of Hawai`i in 1974. In this position, which he occupied until 1984, Matsuda oversaw all matters regarding the 'science reserve' and the construction of additional observatories.

Ski enthusiasts did not give up. In 1975, the context was not favorable to talk of 'recreational' use - the Mauna Kea master plan pushed for by environmentalists was under discussion, and construction had begun for the first major observatory, the Canada-FranceHawaii telescope (Swanner 2017, 300-302; Marichalar, 2021). This did not prevent the Hawaii Ski Association, founded in Honolulu in 1953, to lobby for proper skiing facilities at the summit. Gordon Morse, a member who resided on the Big Island, told a journalist that the primary concerns of skiers were toilets, warming huts, and an easily accessible road. 'Ski tows are secondary concerns', he assured. In fact, after a previous plan to secure State funding for rope tows had failed, the skiers had taken the habit of organizing special shuttle service with vehicles operating 'from the bottom of the runs to the summit', and were therefore mainly interested in having a well-maintained road (HSB 1973). 
The final version of this paper was published as Pascal Marichalar (2021, ahead-of-print) «Skiing, science and sovereignty: A material and political history of the road to Hawai'i's Mauna Kea (1936-2020) », History and Anthropology, DOI: 10.1080/02757206.2021.1983562

The skiers’ political clout was weak. As a local opinion piece had noted a few years earlier, there were probably only a handful of members of the Ski Association on the island, in any case 'hardly a cross-section of Big Island residents' (Rood 1969). Even the issue of clearing the snow from the road remained unresolved, because of the debate over who should be doing it. Charles Shuster, a Big Island engineer who worked with the State Highways Division, was unsure who would have to foot the bill: 'the UH may end up with the responsibility since it has jurisdiction over the land above the 12,000 foot level on the mountain and at present has been maintaing the road and keeping it cleared during heavy snows’, he explained. Yet William McCready, a supervisor at the Mauna Kea Observatory, explained that he had 'been keeping the roads clear by hiring a private contractor from the observatory's budget', and suggested that the astronomers would find it problematic to continue to pay if the priority became helping skiers to reach the top of the slope with their car (Selland 1975). No facilities were built for skiers, and the road remained in the same sorry state.

In 1977, Hawaii County councilman William Kawahara called the road a 'grave hazard.' He wanted it paved:

The present road is dusty and bumpy when dry and often impassable after a rain. Gullies must be filled constantly to make the road passable. 
The final version of this paper was published as Pascal Marichalar (2021, ahead-of-print) «Skiing, science and sovereignty: A material and political history of the road to Hawai'i's Mauna Kea (1936-2020) », History and Anthropology, DOI: 10.1080/02757206.2021.1983562

The journalist reporting on this noted that it was common knowledge that 'the present Mauna Kea summit route from Hale Pōhaku was designed and built at State expense but it was not paved to discourage public access to the observatories.' (HA 1977)

However, could there be such a thing as too little access? On the unpaved portion above Hale Pōhaku, as well as on the notoriously dangerous Saddle Road, there were frequent accidents which implicated locals on weekend daytrips as well as telescope staff ${ }^{3}$. While celebrating the inauguration of the Canada-France-Hawai'i Telescope in 1979, State Senator Neil Abercrombie promised to 'push with all possible haste' to pave the roadway leading to astronomical facilities at Mauna Kea’s summit, and 'the promise drew a thundering ovation from French and Canadian officials attending' (HA 1979).

Not until February 1984 was the University of Hawai'i granted permission by the State Land Board to build a road that would be paved all the way to the summit of the mountain. This was an important green light that other observatory projects had been waiting for. Less than a year later, it was announced that a Californian foundation was choosing Mauna Kea to build what was then the world's biggest operational telescope (in fact two giant telescopes, Keck 1 and Keck 2).

However, the expensive road project had to be segmented into three phases for lack of funding. In 1988, the M. Sonmura Construction Co. of Hilo was granted the contract for the first phase. The funding was a mix of state appropriations and contributions by the telescope

3 The Canada-France Hawai ‘i Telescope’s archives include many pictures of spectacular accidents on Mauna Kea in the 1970s which involved trucks marked with the CFHT logo. 
The final version of this paper was published as Pascal Marichalar (2021, ahead-of-print) «Skiing, science and sovereignty: A material and political history of the road to Hawai'i's Mauna Kea (1936-2020) », History and Anthropology, DOI: 10.1080/02757206.2021.1983562

operators (Clark 1991). The work took three years, because of heavy snowfalls that prevented any progress in winter. Drainage facilities were improved, retaining walls and access roads to other observatories were built, and all roads in the summit area were paved to prevent dust from interfering optically and mechanically with the instruments (Warshauer 2001). In the end, a five mile section between Hale Pōhaku and the summit, though greatly improved, remained unpaved. As a journalist noted, 'drivers will continue to be urged to use four-wheel-drive vehicles only.'

The improved section was inaugurated at the end of 1991. The Board of Regents of the University of Hawai'i decided to name the improved section the John A. Burns summit access road, which was somewhat ironic considering that the former governor had been the most vocal supporter of not making the summit more accessible. But this fact seemed to have dropped from public awareness. At the inauguration, Burns was remembered only as the visionary who had built the first 'Jeep trail' at Akiyama and Kuiper's behest, opening the way (albeit not paving it) for astronomy (Clark 1991).

\section{OCCUPYING THE ROAD AS AN ACT OF SOVEREIGNTY}

In the mid-1970s, a momentous but mostly unnoticed event occurred on the Mauna Kea access road. The construction of the Canada-France-Hawaii telescope was in full swing when, on the morning of Tuesday 25 May 1976, the steelworkers involved decided to walk off the job, in protest over 'intolerable living conditions'. Unlike their employers who commuted daily from Hilo, the workers had to sleep at a makeshift mid-altitude dormitory, in fact a group of flimsy 
The final version of this paper was published as Pascal Marichalar (2021, ahead-of-print) «Skiing, science and sovereignty: A material and political history of the road to Hawai'i's Mauna Kea (1936-2020) », History and Anthropology, DOI: 10.1080/02757206.2021.1983562

cubicles made from pressed sugarcane fiber which was highly flammable (according to worker Ron Koehler, interviewed in Bryson 2007). The food and water was considered horrible, which added up to difficult working conditions because of the lack of oxygen and the harsh climate (HTH 1976a, 1976b).

The protest was unplanned, a so-called wildcat strike. In order to prevent anybody from accessing the construction site, the strikers decided to block the road at the level of Hale Pōhaku, the mid-altitude station. A picture taken that day shows a wooden chair which has been placed in the middle of the dirt path (photograph titled '1976 wildcat strike' featured in Bryson 2007). Sitting on it and viewed from behind, a man dressed in a t-shirt, jeans and safety boots is resting a shotgun upright on his lap, his eyes set on the road which winds up.

This was quite certainly the first time that the Mauna Kea access road was blocked intentionally to prevent people from reaching the summit - that is, on grounds other than the need for regular road maintenance. About a decade earlier, Governor Burns had expressed his concern that the State would not have the legal standing to block the road to undesirable visitors. Ironically, the 1976 wildcat strike exposed another, symmetrical threat to the State's authority over the mountain: a small group of determined people could easily restrict access to the summit by blocking its sole access route. Because their strike was not covered by the union, the steelworkers probably had no legal grounds to cut the road, yet at the end of one day of protest, a deal was struck. The next morning at 8 a.m., the workers were back at the job while a contractor proceeded with 'remodelling of the barracks'. 
The final version of this paper was published as Pascal Marichalar (2021, ahead-of-print) «Skiing, science and sovereignty: A material and political history of the road to Hawai'i's Mauna Kea (1936-2020) », History and Anthropology, DOI: 10.1080/02757206.2021.1983562

The next time the road would be blocked in the context of protest would be almost four decades later. In the meantime, the Keck twin telescopes had been joined on Mauna Kea by other giants named Subaru and Gemini North - in total, thirteen observatories and more than twentytwo domes and dishes. The road's materiality played a central role in the events of the 2010s, as did the debates over the public nature and stewardship of land, and the right to restrict access, issues which had been left unresolved ever since the road's inception ${ }^{4}$.

On 7 October 2014, the California-based 'Thirty Meter Telescope’ Corporation decided to proceed with the groundbreaking ceremony for its new behemoth instrument, in spite of reports of mounting opposition. The officials slated to attend had been discretely bussed the night before to the Hale Pōhaku dormitory and cafeteria, in order to avoid an eventual blockade by a group of kia‘i (protectors) of Mauna Kea who had publicly announced that they would regroup at sunrise for a prayer vigil ceremony at $\mathrm{Pu}^{\prime} \mathrm{u}$ Huluhulu, just across from the intersection between Saddle Road and the Mauna Kea access road.

Later that morning, unaware that the officials were already at Hale Pōhaku, some of the members of the prayer vigil decided to drive up to the proposed telescope's site where the groundbreaking ceremony was to be held. Rangers from the Office of Mauna Kea Management blocked their trucks a few miles from the summit. However, the official caravan of vans had not yet departed from its mid-altitude halt, and when it eventually ascended the mountain, it found

4 Apart from the newspaper articles cited, this section is based on a long ethnographic interview with one of the kia‘i, E. Kalani Flores (Waimea, 27 January 2020), as well as the detailed, concording accounts found in Fujikane (2019) and Casumbal-Salazar (2019). 
The final version of this paper was published as Pascal Marichalar (2021, ahead-of-print) «Skiing, science and sovereignty: A material and political history of the road to Hawai'i's Mauna Kea (1936-2020) », History and Anthropology, DOI: 10.1080/02757206.2021.1983562

the narrow and precipitous road blocked by the kia'i, who were themselves blocked by the rangers.

After about three hours of immobility, some of the officials managed to smuggle themselves on foot past the blockade - officially, to go to the bathroom. In fact, they were discretely collected higher up by vans that were already in the summit area. Some protectors left on foot when they understood what was happening. A video which became viral showed Honoka‘a-born educator Lanakila Mangauil, barefoot and clad in traditional Hawaiian apparel, arriving breathless at the ceremony site and vehemently protesting the fact that the officials were covertly getting on with the groundbreaking, despite their prior assurances to the contrary (BIVN 2014). He was eventually joined by other kia‘i, and the ceremony was cancelled.

There were heavy snowstorms that winter, which protectors interpreted as a sign that Poli'ahu, a female deity of snow, was helping their cause. When the winter weather subsided in late March 2015, trailers loaded with heavy equipment moved to ascend the mountain. This alerted the protectors that construction of the TMT was about to begin. Dozens camped at the level of Hale Pōhaku and occupied the road peacefully, standing with signs or simply sitting in the way.

State officials warned them that they had the right to protest, but not to block the road. On 2 April, 31 protectors were arrested for obstruction of traffic. Due to differences in jurisdiction because of the different reserves that had been delimited on the mountain, the Hawai'i County Police was responsible for arrests on the section below Hale Pōhaku, while 'DOCARE' agents 
The final version of this paper was published as Pascal Marichalar (2021, ahead-of-print) «Skiing, science and sovereignty: A material and political history of the road to Hawai'i's Mauna Kea (1936-2020) », History and Anthropology, DOI: 10.1080/02757206.2021.1983562

(Division of conservation and resources enforcement) acting on behalf of the State Department of Land and Natural Resources proceeded to arrest those above. Among those arrested were respected kupuna (elders) such as 70 year-old Moanike‘ala Akaka of Hilo: the images of her and others being handcuffed caused outrage and widespread sympathy for the movement, in Hawai ‘ $\mathrm{i}$ and abroad (Hurley 2015a). ${ }^{5}$

On Saturday 20 June, the Chairman of the TMT International Observatory board announced that construction crews would be heading back up as of the following Wednesday (Hurley 2015b). When the caravan of workers, police and TMT officials got to Hale Pōhaku, this time they faced not dozens but hundreds of kia'i. The protectors started walking in sequence across the crosswalk in order to slow the convoy without committing an arrestable offence. Hours later, the caravan had only managed to cover the few hundred meters until the start of the gravel summit access road. There, the drivers of the first trucks discovered that rocks taken from the retaining walls had been strewn by kia' $i$ across the summit access road, under the cover of Lilinoe (the mist). Two ahu (traditional stone altars) had also been built on the road. The construction crews turned back.

The rocks and ahu were removed during the following days, but the road remained closed all through the summer (Hurley 2015c). The Department of Land and Natural Resources issued an emergency rule that forbade access to the mountain during the night, but it was invalidated later that fall as a result of legal action from the kia'i. At the beginning of December 2015, the

5 Moanike'ala Akaka died on 15 April 2017. Her important role in demilitarization struggles and the Native Hawaiian community is highlighted in Akaka et al., 2018, in particular the introduction by Noelani GoodyearKa‘ōpua. 
The final version of this paper was published as Pascal Marichalar (2021, ahead-of-print) «Skiing, science and sovereignty: A material and political history of the road to Hawai'i's Mauna Kea (1936-2020) », History and Anthropology, DOI: 10.1080/02757206.2021.1983562

Supreme Court of Hawai'i invalidated the permit that allowed construction of the TMT on conservation lands, considering that due process had not been followed. The astronomers had to start over the entire permit application.

Legal and administrative hurdles halted the project until the end of June 2019. Governor Ige announced that construction would resume during the summer. On 27 June, the editorial of the clearly pro-TMT Honolulu Star-Advertiser called to protect the rights of the Native Hawaiian kia'i, yet drew the line at protests that would consist of 'blocking a state-owned road' (HSA 2019a). The public nature of the road was now used as an argument in support of the State's right to decide the legitimate uses of Mauna Kea.

On Wednesday 10 July, Ige announced that the Mauna Kea access road would be closed as of the following Monday, 7 a.m., to allow heavy equipment to proceed to the construction site (Hurley 2019a). During the weekend, dozens of police officers were flown in, and police vans that could be used to transport officers and arrestees were shipped to Hawai'i Island (Dayton 2019a).

Since the April events, the government had been discretely working on the road's materiality in order to make the kia'i mobilization more difficult. Long, uninterrupted guardrails had been erected on either side of the road around Hale Pōhaku to prevent cars from parking. The crosswalk that had allowed kia'i to slow the previous caravan had been erased. The protectors decided they had to find an alternate basecamp. Ironically, the State-imposed restrictions at Hale Pōhaku forced the kia‘i down to a site which was more easily accessible and 
The final version of this paper was published as Pascal Marichalar (2021, ahead-of-print) «Skiing, science and sovereignty: A material and political history of the road to Hawai'i's Mauna Kea (1936-2020) », History and Anthropology, DOI: 10.1080/02757206.2021.1983562

had a far more welcoming climate: the intersection of the Saddle road and the Mauna Kea access road, across from Pu'u Hulululu, which the kia‘i had declared a pu'uhonua (place of refuge).

Under cover of night in the morning of Monday 15 July, eight kia'i chained themselves to the cattle grid that was located on Mauna Kea access road, about 150 meters from the intersection. Hundreds of others came to support them. When the police arrived, they explained that they would have to arrest seven of the chained protectors for blocking the road; the eighth, locked under the cattle grid, would be left alone because he was not blocking the road. But the 'extraction team’ supposed to cut the chains never arrived, and the police left at 4 p.m. (Hurley 2019b).

The next day, hundreds of kia‘i were standing guard at Pu'u Huluhulu. Some of them manned a checkpoint at the beginning of Mauna Kea Access Road. Two dozen kupuna sat in chairs underneath a tent in the middle of the access road, and when the police came to negotiate, they volunteered to be arrested. It was eventually announced that there would be no arrests if the kia' $\mathrm{i}$ let twenty-two astronomy workers ascend to the existing observatories, which the kia' $\mathrm{i}$ agreed to do (Hurley 2019c).

The third day (17 July 2019), about a thousand people were gathered at the base of the Mauna Kea access road. In the morning, thirty-three kupuna who were sitting under the tent in the middle of the road were arrested, but hundreds of kia'i who were also blocking the road refused to move. Tension increased when the police moved to arrest them too, at which point some kia'i started to block the Saddle Road by parking their car across the highway, causing 
The final version of this paper was published as Pascal Marichalar (2021, ahead-of-print) «Skiing, science and sovereignty: A material and political history of the road to Hawai'i's Mauna Kea (1936-2020) », History and Anthropology, DOI: 10.1080/02757206.2021.1983562

major traffic disruption. At the beginning of the afternoon, the police agreed to leave the Mauna Kea access road if the owners of the cars blocking the highway removed them. Andre Perez, one of the kia'i, exulted: 'They called it a day. They went home. We still got the road. We still control the road' (Dayton 2019b).

That same afternoon, Governor Ige issued an emergency proclamation, explaining that 'the number of protesters has swelled and their blockage of roads and highways creates a dangerous situation.' The state of emergency suspended various laws, allowing the State to evacuate areas if the situation warranted it and to forbid anybody from going up Mauna Kea. The access road was officially closed (Cocke 2019a).

The fourth day (18 July 2019), hundreds of kia'i were sitting at the entrance of the access road, but there was no attempt to dislodge them. Over the following weeks, the crowd of kia'i swelled to reach many thousand, with hundreds sleeping on-site. Life organized around ritual ceremonies known as the daily protocol. It took place on the Mauna Kea access road itself, which was renamed Ala Hulu Kupuna (the road of esteemed elders). The existing observatories remained closed until mid-August, though the kia'i announced they did not wish to block astronomy workers from ascending.

A few days after the July events, Paul Neves, a Hawaiian cultural practitioner, challenged the governor's emergency rules which forbade all from climbing the mountain, including, for the first time ever, Hawaiian cultural practitioners. The court ruled in favor of the plaintiff, stating that he, and he only, 'may access the summit of Mauna Kea only when a convoy [of construction 
The final version of this paper was published as Pascal Marichalar (2021, ahead-of-print) «Skiing, science and sovereignty: A material and political history of the road to Hawai'i's Mauna Kea (1936-2020) », History and Anthropology, DOI: 10.1080/02757206.2021.1983562 equipment] is not travelling on the Mauna Kea access road.' Though Neves was allowed on the mountain, his presence on the road was only accepted if it remained marginal, in the literal sense: the judges felt necessary to precise that, should he want to ascend on foot, he should do it 'as near to the edge of the road as practicable’ (Neves 2019).

In August 2019, State Senator Kai Kahele questioned whether the State Department of Transportation had any legal jurisdiction over the Mauna Kea access road - and whether the police even had the right to prevent kia‘i from occupying it (Cocke 2019b), as some sections of the road were located on Hawaiian Home Lands. The Department of Hawaiian Home Lands and three Native Hawaiians sued the State, considering that the section which they defined as the 'Mauna Kea access road,' from the Saddle Road till a little over Hale Pōhaku - by opposition to the 'summit access road' higher up - had been built on Hawaiian home lands without authorization nor compensation through a land swap (BIVN 2020). As Edward Halealoha Ayau one of the plaintiffs, explained before the Board of Trustees of the Office of Hawaiian Affairs in September 2019: 'You had this practice of State agencies, oftentimes supported by executive orders of the Governor, regularly taking - if you will, stealing - Hawaiian Home Lands, without authorization from the commission, and without paying for it. The Mauna Kea access road is Hawaiian home lands, the University of Hawai'i stole it from the trust by building a road over it, and never paying for it'(BIVN, 2019). At the time of writing, this case was still under review.

In December 2020, Ige announced that a temporary agreement with the kia'i had been reached. As TMT construction efforts would not resume before the end of the winter, the 
The final version of this paper was published as Pascal Marichalar (2021, ahead-of-print) «Skiing, science and sovereignty: A material and political history of the road to Hawai'i's Mauna Kea (1936-2020) », History and Anthropology, DOI: 10.1080/02757206.2021.1983562

protectors agreed that the road could be reopened to the public and they would not attempt to block it. In March 2020, the Governor issued statewide stay-at-home orders because of the coronavirus pandemic. For the second time in less than a year, the telescopes closed. Most kia' $\mathrm{i}$ announced they were leaving their camp, by concern for health and because of their feeling that there was 'no imminent threat from TMT' (WHT 2020).

\section{Conclusion}

In the 2010s, the dramatic sequence of events surrounding the TMT project placed the question of land tenure and sovereignty in Hawai'i under the spotlight. As I have tried to show in this history of the mountain's access road, these issues were in fact always present on Mauna Kea, starting with the first 'CCC' trail projects in the 1930s. A State forester wished to develop skiing, and was granted the right, the funding and the manpower to build a trail. A Hilo businessman dreamed to erect telescopes, and the State built a road within weeks to accomodate him. An astronomer wanted to assert his dominion over the summit of Mauna Kea, and a liberal lease assorted with generous zoning provisions was granted to the ad hoc institution he had just created. Each of these projects were carried out in the name of economic development, with little regard for prior uses of the land, and more or less exclusively of competing uses, with the endorsement of the Territorial then State government. Furthermore, the construction of the roads leading to the summit of Mauna Loa and Mauna Kea was made possible in great part by the cheap labor of men in positions of vulnerability or duress ('CCC Boys', prisoners, soldiers). 
The final version of this paper was published as Pascal Marichalar (2021, ahead-of-print) «Skiing, science and sovereignty: A material and political history of the road to Hawai'i's Mauna Kea (1936-2020) », History and Anthropology, DOI: 10.1080/02757206.2021.1983562

Throughout this history, the material aspect of the road - in particular the ease with which one could access the summit - can be explained as much by political considerations over who is entitled to decide of the mountain's fate and to climb it, as by the more classic construction difficulties and budget shortfalls; material issues are entangled with political visions. As of the moment astronomy arrived on the mountain, tensions appeared between the goal of finishing the road in order to make the summit more accessible for scientists, and some actors’ satisfaction with leaving it unfinished to ward off unwanted users. The public nature of the road and the lands to which it led emerged as a central issue, just as the rebirth of the Hawaiian sovereignty movement put into question what the notion of 'public' really meant in a State that was born from an illegitimate overthrow and annexation.

This study confirms that, as the historian of Hawaiian roads Dawn Duensing notes, 'more than just technology and construction details, the story of roads reflects the various threads that weave together Hawai 'i’s social, political, economic, leisure, and environmental history.' (Duensing 2015, 6) In particular, the material and political history of the Mauna Kea access road is a synecdoche of the unresolved political conflict over land and sovereignty that defines Hawaiian history ever since the $19^{\text {th }}$ century. 
The final version of this paper was published as Pascal Marichalar (2021, ahead-of-print) «Skiing, science and sovereignty: A material and political history of the road to Hawai'i's Mauna Kea (1936-2020) », History and Anthropology, DOI: 10.1080/02757206.2021.1983562

\section{References}

Akaka, Moanike‘ala, and Maxine Kahaulelio, Terrilee Keko‘olani-Raymond, Loretta Ritte, Noelani Goodyear-Ka‘ōpua. 2018. Nā Wāhine Koa: Hawaiian Women for Sovereignty and Demilitarization. Honolulu: Hawai'inuiākea School of Hawaiian Knowledge ; University of Hawai'i Press.

Akiyama, Mitsuo. 1963. “Letter to Saburo Okazaki”. 20 June 1963. Mitsuo Akiyama Archival Collection, malamamaunakea.org/library.

Baker, Byron. 1967a. “Burns’ Big Isle plans opposed”. Honolulu Star-Bulletin. 20 October 1967.

Baker, Byron. 1967b.“Burns against road to top of Mauna Kea”. Honolulu Star-Bulletin. 20 October 1967.

Bayor, Ronald. 1988. "Roads to Racial Segregation: Atlanta in the Twentieth Century”. Journal of Urban History 15: 3-21.

Bennett Hill, Virginia. 1941. "Prison labor sought for road to Kona”. Hilo Tribune-Herald, 26 March 1941.

Bergin, Billy. 2004. Loyal to the Land: the Legendary Parker Ranch, 750-1950. Honolulu: University of Hawai'i Press.

BIVN (Big Island Video News). 2014. “TMT opponents halt groundbreaking ceremony”. 8 October 2014, youtu.be/SZ4Gt35hs-s.

BIVN (Big Island Video News). 2019. “OHA: Edward Halealoha Ayau On Mauna Kea Access Road”. 19 September 2019, youtu.be/1cG29EYkD8c.

BIVN (Big Island Video News). 2020. "Breach of trust lawsuit filed over Mauna Kea access road”. 13 February 2020, bigislandvideonews.com/2020/02/13/breach-of-trust-lawsuit-filed-overmauna-kea-access-road.

Bryan, Jack. 1967. Big Isle ski meet draws peak crowd. Honolulu Star-Bulletin, 6 March 1967.

Bryson, Liz. 2007. Gathering the forgotten voices: an Oral History of the Canada-France-Hawaii Telescope's Early Years. DVD, CFHT Library.

Case, Emalani. "I Ka Piko, To the Summit: Resistance from the Mountain to the Sea”. The Journal of Pacific History 54 (2): 166-181.

Casumbal-Salazar, Iokepa. “'Where are your sacred temples?' Notes on the struggle for Mauna a Wākea”, in eds. Hōkūlani K. Aikau and Vernadette Vicuña Gonzalez, Detours: a Decolonial Guide to Hawai ‘i (Durham, NC: Duke Univ. Press, 2019), 200-210.

Clark, Hugh. 1991. “Mauna Kea road to be dedicated”. Honolulu Advertiser, 17 December 1991. Cocke, Sophie. 2019a. “State of emergency”. Honolulu Star-Advertiser, 18 July 2019. 


\section{The final version of this paper was published as Pascal Marichalar (2021, ahead-of-print) «Skiing, science and sovereignty: A material and political history of the road to Hawai'i's Mauna Kea (1936-2020) », History and Anthropology, DOI: 10.1080/02757206.2021.1983562}

Cocke, Sophie. 2019b. “Questions arise over Mauna Kea road”. Honolulu Star-Advertiser, 15 August 2019.

Cooper, George and Gavan Daws. 1985. Land and Power in Hawaii. Honolulu: University of Hawai'i Press.

Dayton, Kevin. 2019a. “Gearing up”. Honolulu Star-Advertiser, 14 July 2019.

Dayton, Kevin. 2019b. "Highway closed, 33 arrested as TMT protests ratchet up”. Honolulu StarAdvertiser, 18 July 2019.

Denning, Andrew. 2014. Skiing into Modernity: A Cultural and Environmental History. Oakland: University of California Press.

Duensing, Dawn E. 2009. "Haleakalā Highway: Bringing the World to Maui”. The Journal of Pacific History 44 (3): 303-324.

Duensing, Dawn E. 2015. Hawai 'i's Scenic Roads: Paving the Way for Tourism in the Islands. Honolulu: University of Hawai'i Press.

Freed, Libbie. 2010. "Networks of (colonial) power: roads in French Central Africa after World War I". History and Technology 26 (3): 203-223.

Fujikane, Candace. "Mapping Abundance on Mauna a Wākea as a Practice of Ea”. Hūlili: Multidisciplinary Research on Hawaiian Well-Being 11 (1): 23-54.

Goodyear-Ka‘ōpua, Noelani. 2014. “Introduction” in eds. Noelani Goodyear-Ka‘ōpua, Ikaika Hussey and Erin Kahunawaika'ala Wright, A Nation Rising: Hawaiian Movements for Life, Land, and Sovereignty (Durham, NC: Duke University Press), 1-33.

Hamilton, Thomas H. 1963. "Letter to Mitsuo Akiyama”. 15 July 1963. Hawai‘i State Archives (records of Governor John A. Burns), HSA Gov 13-47.

HA (Honolulu Advertiser). 1970. "Mauna Kea road work: Burns promises quick action”. 10 January 1970.

HA (Honolulu Advertiser). 1977. "Summit road said hazard”. 2 September 1977.

HA (Honolulu Advertiser). 1979. “Mauna Kea’s summit road gets a boost”. 29 September 1979.

HDT (Hilo Daily Tribune). 1922. "Plans outlined by Judd for Hilo Forest Reserve”. 27 January 1922.

Hobart, Hi'ilei Julia. 2019. "At Home on the Mauna: Ecological Violence and Fantasies of Terra

Nullius on Maunakea’s Summit.” Native American and Indigenous Studies 6 (2): 30-50.

HSA (Honolulu Star-Advertiser). 2019. “Let TMT, respect proceed together”. 27 June 2019.

HSB (Honolulu Star-Bulletin). 1921. "The Mauna Loa Highway”. 1 August 1921.

HSB (Honolulu Star-Bulletin). 1941. “Joint resolution H.J.R 27 (Hawaii House)”. 24 March 1941.

HSB (Honolulu Star-Bulletin). 1961. “\$2 million eyed for Hawaii Geophysics Institute”. 22 August 1961.

HSB (Honolulu Star-Bulletin). 1973. “Big Isle lures skiers”. 2 December 1973. 
The final version of this paper was published as Pascal Marichalar (2021, ahead-of-print) «Skiing, science and sovereignty: A material and political history of the road to Hawai'i's Mauna Kea (1936-2020) », History and Anthropology, DOI: 10.1080/02757206.2021.1983562

HSB (Honolulu Star-Bulletin). 1984. “Forester L.W. Bryan, 88, dies at Big Island Home”. 2 February 1984.

HTH (Hilo Tribune-Herald). 1936. "Mauna Kea goes alpine! First skis travel slope”. 11 February 1936.

HTH (Hilo Tribune-Herald). 1937a. "Skiing season in Hawaii is now officially opened”. 2 January 1937.

HTH (Hilo Tribune-Herald). 1937b. "March of Time films taken. 23 February 1937.

HTH (Hilo Tribune-Herald). 1939a. "Women climb to snow area”. 22 January 1939.

HTH (Hilo Tribune-Herald). 1939b. “Mauna Kea Truck trail project is started”. 19 February 1939. HTH (Hilo Tribune-Herald). 1939c. "Letter to the editor from Bernard Powers of the Hawaii Ski Club”. 25 February 1939.

HTH (Hilo Tribune-Herald). 1939d. "CCC Boys building new mountain house”. 8 August 1939. HTH (Hilo Tribune-Herald). 1939e. "New resthouse erected at 9500 foot elevation on slopes of Mauna Kea”. 17 December 1939.

HTH (Hilo Tribune-Herald). 1941. "Senators ask Hilo to Kona Saddle Road”. 22 February 1941. HTH (Hilo Tribune-Herald). 1944. "William J. Payne reelection bid”. 5 November 1944. HTH (Hilo Tribune-Herald). 1951a. "Big Isle tropic snow could be tourist capital. 11 November 1951.

HTH (Hilo Tribune-Herald). 1951b. "Picnic place in the sky”. 19 December 1951.

HTH (Hilo Tribune-Herald). 1955. “Opportunities for Maui’s economic expansion studied”. 30 August 1955.

HTH (Hilo Tribune-Herald). 1963. "New Maui equipment to boost knowledge of the Sun”. 16 September 1963.

HTH (Hawaii Tribune-Herald). 1972a. "Mauna Kea tramway envisioned by Farias”. 18 February 1972.

HTH (Hawaii Tribune-Herald). 1972b. "Mauna Kea access road bids called by State unit”. 28 April 1972.

HTH (Hawaii Tribune-Herald). 1976a. "Mauna Kea crew walks off of job”. 25 May 1976.

HTH (Hawaii Tribune-Herald). 1976b. "Workers return to Mauna Kea”. 26 May 1976.

HTH (Hawaii Tribune-Herald). 1985. "Museum acquires Bryan collection”. 22 February 1985. Hurley, Timothy. 2015a. "Anti-telescope protesters arrested atop Mauna Kea”. Honolulu StarAdvertiser, 3 April 2015.

Hurley, Timothy. 2015b. "Showdown over telescope looms anew". Honolulu Star-Advertiser, 22 June 2015.

Hurley, Timothy. 2015c. "Progress halted”. Honolulu Star-Advertiser, 26 June 2015.

Hurley, Timothy. 2019a. “Telescope work set to start”. Honolulu Star-Advertiser, 11 July 2019.

Hurley, Timothy. 2019b. "Protesters claim round one”. Honolulu Star-Advertiser, 16 July 2019. 


\section{The final version of this paper was published as Pascal Marichalar (2021, ahead-of-print) «Skiing, science and sovereignty: A material and political history of the road to Hawai'i's Mauna Kea (1936-2020) », History and Anthropology, DOI: 10.1080/02757206.2021.1983562}

Hurley, Timothy. 2019c. "Holding the line”. Honolulu Star-Advertiser, 17 July 2019.

Jefferies, John. n.d. “Astronomy in Hawai'i 1964-1970”. Institute for Astronomy, ifa.hawaii.edu/history/jefferies.

Judd, C.S. 1935. "Riddance of 40,000 wild sheep on Hawaii part of CCC forestry program in islands". Honolulu Advertiser, 9 September 1935.

Kauanui, J. Kēhaulani. 2008. Hawaiian Blood: Colonialism and the Politics of Sovereignty and Indigeneity. Durham, NC: Duke University Press.

Kauanui, J. Kēhaulani. 2018. Paradoxes of Hawaiian Sovereignty: Land, Sex, and the Colonial Politics of State Nationalism. Durham, NC: Duke University Press.

Kuiper, Gerard P. 1964. “Address given at Mauna Kea station dedication”. 20 July 1964. Mitsuo Akiyama Archival Collection, malamamaunakea.org/library.

Maly, Kepā \& Onaona Maly. 2005. Mauna Kea - "Ka Piko Kaulana o Ka 'Āina": A collection of oral history interviews documenting historical accounts and recollections of Mauna Kea and the mountain lands of Hamakua, Hilo and South Kohala, on the Island of Hawai 'i. Office of Mauna Kea Management.

Marichalar, Pascal. 2021. “ ‘This Mountain is It': How Hawai 'i’s Mauna Kea was 'Discovered' for Astronomy”. The Journal of Pacific History 56 (2): pages tbd.

McGregor, Davianna Pōmaika'i. 2010. "Statehood: Catalyst of the Twentieth-Century Kanaka 'Ōiwi Cultural Renaissance and Sovereignty Movement”. Journal of Asian American Studies 13(3): 311-326.

Mims, Forrest M. 2012. Hawai 'i’s Mauna Loa Observatory: Fifty Years of Monitoring the Atmosphere. Honolulu: University of Hawai'i Press.

Mohl, Raymond A. 1993. "Race and Space in the Modern City: Interstate-95 and the Black Community in Miami”, in Arnold R. Hirsch and Raymond A. Mohl, eds. Urban Policy in Twentieth-Century America (New Brunswick, N.J.: Rutgers University Press), 100-158.

Neves, Paul Kevin vs. Governor Ige. 2019. “Civil n 19-1-1134-07, provisional order”. 23 July 2019.

Olival, Thelma B. 1955. "Snow fun”. Honolulu Star-Bulletin, 22 January 1955.

Pacific Consulting Services. 2010. "Architectural inventory survey of Hale Pōhaku resthouses 1 and 2 and comfort station". Office of Mauna Kea Management, dlnr.hawaii.gov/mk/files/2016/10/Ex.-A-123.pdf.

Rood, Jim. 1969. "Other projects more deserving than Mauna Kea skiing scheme”. Hawaii TribuneHerald, 23 April 1969.

Salazar, Joseph. 2014. "Multicultural Settler Colonialism and Indigenous Struggle in Hawai'i: The Politics of Astronomy on Mauna A Wākea”. PhD diss., University of Hawai'i.

Schorghofer, Norbert, Elianna Kantar and Puakea Nogelmeier. 2014. "Snow on the Summits of Hawai ‘i Island: Historical Sources from 1778 to 1870”. The Hawaiian Journal of History 48: 89113. 
The final version of this paper was published as Pascal Marichalar (2021, ahead-of-print) « Skiing, science and sovereignty: A material and political history of the road to Hawai'i's

Mauna Kea (1936-2020) », History and Anthropology, DOI: 10.1080/02757206.2021.1983562

Selland, Jan. 1975. “\$300,000 set aside for ski facilities”. Hawaii Tribune-Herald, 18 April 1975. Silva, Noenoe K. 2004. Aloha Betrayed: Native Hawaiian Resistance to American Colonialism. Durham, NC: Duke University Press.

Shih, Ashanti. 2019. "The Most Perfect Natural Laboratory in the World: Making and Knowing Hawaii National Park”. History of Science 57, no. 4: 493-517.

Stauffer, Robert H. 2004. Kahana: How the Land was Lost. Honolulu: University of Hawai'i Press. Sugrue, Thomas. 2014. The Origins of the Urban Crisis: Race and Inequality in Postwar Detroit (Princeton, NJ: Princeton University Press).

Swanner, Leandra A. 2014. "Mountains of Controversy: Narrative and the Making of Contested Landscapes in Postwar American Astronomy”. PhD diss., Harvard University.

Swanner, Leandra A. 2017. "Instruments of Science or Conquest? Neocolonialism and Modern American Astronomy”. Historical Studies in the Natural Sciences 47(3): 293-319.

Thompson, Foreman. 1946. "Mauna Kea: a winter wonderland in the sky". Hilo Tribune-Herald, 17 February 1946.

Warshauer, Kent. 2001. “Story of the road to Mauna Kea’s summit”. Hawaii Tribune-Herald, 4 November 2001.

Weart, Spencer. 1977. “Oral history interview of John Jefferies”. American Institute of Physics, aip.org/history-programs/niels-bohr-library/oral-histories/4693.

WHT (West-Hawaii Today). 2020. “TMT protesters leave camp due to virus concerns”. 28 March 2020.

Whitten, Harry. 1985. "Family donates chronicles of Big Island forester Bryan”. Honolulu StarBulletin, 7 March 1985. 
The final version of this paper was published as Pascal Marichalar (2021, ahead-of-print) «Skiing, science and sovereignty: A material and political history of the road to Hawai'i's Mauna Kea (1936-2020) », History and Anthropology, DOI: 10.1080/02757206.2021.1983562

\section{Abstract (232 words)}

Mauna Kea, the tallest volcano on Hawai'i Island, has become a mountain familiar to many in the Pacific and around the world, as a result of the massive mobilizations in which those who identified as kia'i (protectors) of the mountain opposed the construction of a giant Thirty Meter Telescope (TMT) at the summit. This article retraces the history of the Mauna Kea access road, based on a study of the English-language newspaper record as well as ethnographic and archival material. From the road's inception in the 1930s onward, economic interests, political conflicts, and relations of domination appear intertwined with the very materiality of the road: its route, surface, safety, maintenance, as well as features such as cattle grids, crosswalks, and guardrails. Three political strategies centrally involved the notion of a Mauna Kea access road. Starting in the 1930s, businessmen and government officials pushed for a road, and later for its improvement, in order to make the mountain more accessible, in particular for skiing. As of the 1960s, this push was paralleled and contradicted by another strategy which consisted in keeping the mountain not too accessible, in part because of what some perceived as a competition between recreational and scientific uses - skiing vs. science. A third political strategy involved the road as a site from which to question the notion of public ownership and to affirm sovereignty. The history of the Mauna Kea access road appears as a synecdoche of the political conflict over land and sovereignty that defines Hawaiian history since the 19th century.

Keywords

Hawai‘i, Mauna Kea, Development, Tourism, Science, Land, Sovereignty 
The final version of this paper was published as Pascal Marichalar (2021, ahead-of-print) «Skiing, science and sovereignty: A material and political history of the road to Hawai'i's

Mauna Kea (1936-2020) », History and Anthropology, DOI: 10.1080/02757206.2021.1983562

\section{Figure 1}

Topographic Map in French of the island of Hawai'i, 2008, (c) Sémhur / Wikimedia Commons / CC-BY-SA-3.0.

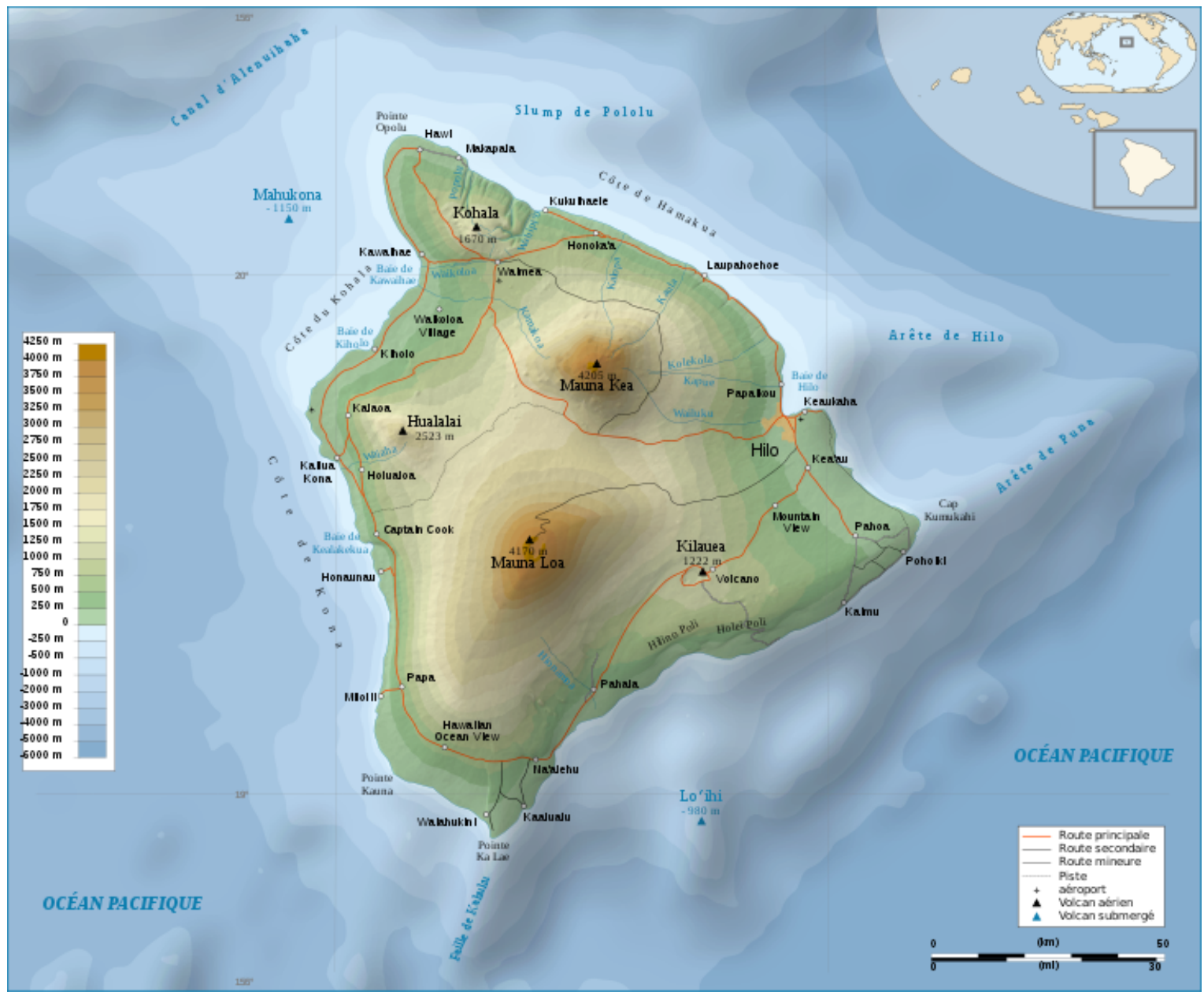


The final version of this paper was published as Pascal Marichalar (2021, ahead-of-print) «Skiing, science and sovereignty: A material and political history of the road to Hawai'i's

Mauna Kea (1936-2020) », History and Anthropology, DOI: 10.1080/02757206.2021.1983562

Figure 2

Author's map of the Mauna Kea access and summit road and Saddle, as observed in January 2020.

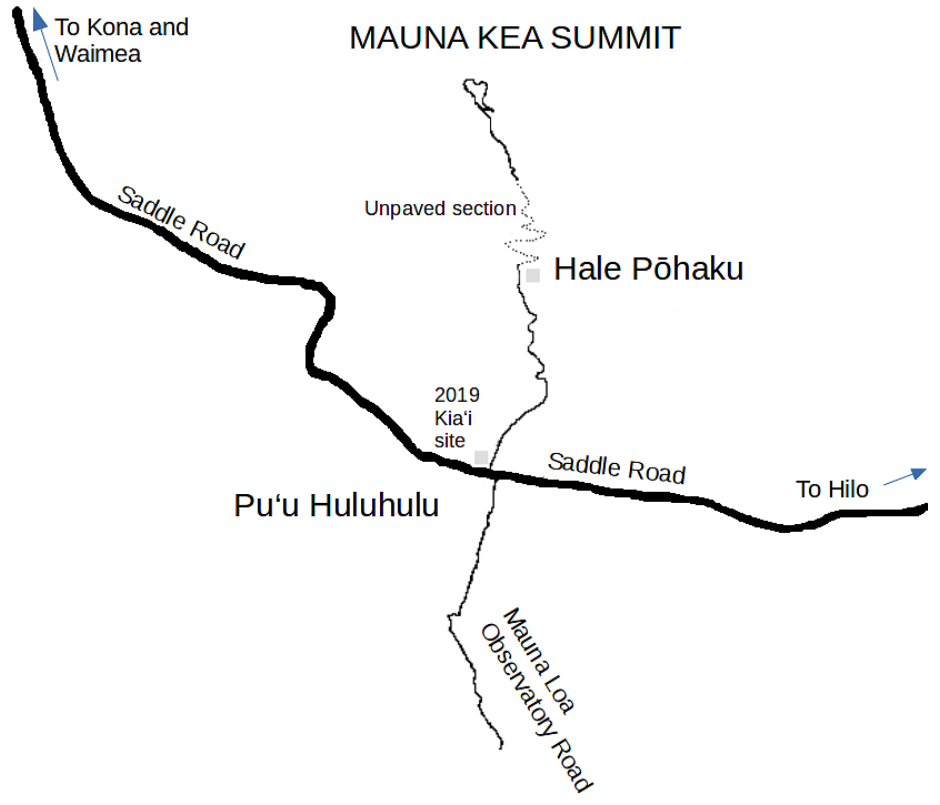

